\section{Inheritance of Resistance to Zucchini Yellow Fleck Virus in Cucumis sativus L.}

\author{
F. Gilbert-Albertini \\ Station de Pathologie Végétale, Institut National de la Recherche Agronomique, \\ B.P.94, 84143 Montfavet Cedex, France
}

M. Pitrat

Station d'Amélioration des Plantes Maraîchères, Institut National de la Recherche Agronomique, B.P.94, 84143 Montfavet Cedex, France

\section{H. Lecoq ${ }^{1}$}

Station de Pathologie Végétale, Institut National de la Recherche Agronomique, B.P.94, 84143 Montfavet Cedex, France

Additional index words. cucumber, genetic, potyvirus

\begin{abstract}
Zucchini yellow fleck virus (ZYFV) is a potyvirus that occurs in cucurbits grown in some Mediterranean countries. 'Marketer' cucumber responded to ZYFV infection with a severe mosaic, stunting, and leaf and fruit deformation. A high level of resistance to this virus was found in a single plant selection of 'Taichung Mou Gua' (TMG) cucumber from Taiwan. In $\mathrm{F}_{2}$ and backcross populations involving TMGX 'Marketer', the resistance to ZYFV was determined to be conferred by a single recessive gene, to which the symbol $z y f$ is assigned.
\end{abstract}

Several viruses may cause major losses in cucumber (Cucumis sativus L.) crops, including three potyviruses [zucchini yellow mosaic virus (ZYMV), papaya ringspot virus Type $\mathrm{W}$ (PRSV-W), and watermelon mosaic virus type 2 (WMV2)] (Lisa and Lecoq, 1984; Purcifull et al., 1984a, 1984b). Zucchini yellow fleck virus (ZYFV) is considered a distinct member of the potyviruses, different from the other cucurbit potyviruses (ZYMV, PRSV-W, WMV2) regarding serological and host range properties (Vovlas et al., 1981). Nevertheless, a distant relationship exists between ZYFV andPRSV-W (Baker etal., 1987; Quiot-Douine et al., 1990). ZYFV has been reported in some Mediterranean countries, where it has caused severe epidemics in cucumber and squash (Cucurbita pepo L.) by inducing severe mosaic and vein banding symptoms on leaves and fruit (Avgelis, 1985; Gilbert-Albertini and Lecoq, 1994; Katul and Makkouk, 1987; Vovlas et al., 1981, 1983). Although ZYFV has not been found yet in cultivated cucurbit plants in France, it was recently isolated from squirting cucumber [Ecballium elaterium (L.) A. Rich.] in southeastern France. ZYFV survival often has been associated with the pres-

Received for publication 28 Jan. 1994. Accepted for publication 23 Sept. 1994. We thank R. Provvidenti for providing 'Taichung Mou Gua' cucumber seeds and for a critical review of this manuscript. The cost of publishing this paper was defrayed in part by the payment of page charges. Under postal regulations, this paper therefore must be hereby marked advertisement solely to indicate this fact.

${ }^{1}$ To whom reprint requests should be addressed. ance of this resistance. ence of squirting cucumber, a perennial weed common in the Mediterranean basin (Avgelis, 1985; Gilbert-Albertini and Lecoq, 1994; Vovlas et al., 1981, 1983). Removing this weed around vegetable fields could efficiently limit ZYFV spread (Avgelis, 1985).

Various genes govern resistances to potyviruses in cucumber accessions. Cohen et al. (1971) described resistance to WMV2 governed by a dominant gene ( $W m v)$, and Wang et al. (1984) reported resistance to PRSV-W governed by a recessive gene (prsv). Provvidenti (1985) reported that a line derived from a single 'Taichung Mou Gua' plant from Taiwan ('TMG-1') was resistant to ZYMV, PRSV-W, WMV2, and cucumber mosaic virus (CMV). The resistance to ZYMV is governed by one recessive gene (zym) (Provvidenti, 1987), WMV2 resistance by two recessive genes, and PRSV resistance by one dominant gene (Wai and Grumet, 1991). 'TMG-2', another single plant selection derived from TMG, is resistant to ZYMV, WMV2, and PRSV. In this study, we determined that 'TMG-2' is also resistant to ZYFV and analyzed the inherit-

Table 1. Resistance segregation in progenies from crosses between the susceptible 'Marketer' and the resistant inbred line 'TMG-2' after inoculation with a French isolate of zucchini yellow fleck virus (ZYFV-Fr)

\begin{tabular}{|c|c|c|c|c|c|c|}
\hline \multirow[b]{2}{*}{ Generation } & \multicolumn{3}{|c|}{ No. plant } & \multicolumn{3}{|c|}{$\chi^{2}$} \\
\hline & Total & $\mathrm{S}^{\mathrm{z}}$ & $\mathrm{R}^{\mathrm{y}}$ & Ratio & Value & Probability \\
\hline$\overline{\mathrm{P}_{1}}=$ Marketer & 23 & 23 & 0 & & & \\
\hline $\mathrm{P}_{2}=\mathrm{TMG}-2$ & 26 & 0 & 26 & & & \\
\hline $\mathrm{F}_{1}\left(\mathrm{P}_{1} \times \mathrm{P}_{2}\right)$ & 20 & 20 & 0 & & & \\
\hline $\mathrm{F}_{1}\left(\mathrm{P}_{2} \times \mathrm{P}_{1}\right)$ & 43 & 43 & 0 & & & \\
\hline $\mathrm{F}_{2}\left(\mathrm{P}_{2} \times \mathrm{P}_{1}\right)$ & 232 & 168 & 64 & $3: 1$ & 0.83 & 0.36 \\
\hline BCs: $\mathrm{P}_{1}\left(\mathrm{P}_{2} \times \mathrm{P}_{1}\right)$ & 65 & 65 & 0 & & & \\
\hline BCr: $\mathrm{P}_{2}\left(\mathrm{P}_{2} \times \mathrm{P}_{1}\right)$ & 105 & 54 & 51 & $1: 1$ & 0.09 & 0.77 \\
\hline
\end{tabular}

Seed samples of the Taiwanese cucumber 'TMG-2' were provided by R. Provvidenti (Cornell Univ., Geneva, N.Y.). This line was crossed with the susceptible cultivar Marketer, and the $\mathrm{F}_{2}, \mathrm{BCs}$ ('Marketer' $\mathrm{x} \mathrm{F}_{1}$ ), and $\mathrm{BCr}$ ('TMG-2' $\times \mathrm{F}_{1}$ ) generations were produced. Seeds were sown in flats with potting soil and then transplanted into $500-\mathrm{cm}^{3}$ square pots filled with the same potting soil. Experiments were conducted in an insect-proof greenhouse maintained at 20 to $25 \mathrm{C}$.

A ZYFV [ZYFV-French isolate (ZYFV$\mathrm{Fe})]$ isolate was obtained from squirting cucumber collected in southeastern France (Gilbert-Albertini and Lecoq, 1994) and maintained in Cucurbita pepo L. ('Diamant'). At the cotyledon stage, seedlings were mechanically inoculated by the Lecoq et al. (1979) method commonly used in our laboratory.

Serological tests were conducted in double antibody sandwich enzyme-linked immunosorbent assay (DAS-ELISA) (Clark and Adams, 1977), using a polyclonal antiserum againstZYFV-Fr, IgGs, and alkaline phosphatase-conjugated IgGs obtained in our laboratory (Gilbert-Albertini and Lecoq, 1994). All absorbance values at $405 \mathrm{~nm}\left(\mathrm{~A}_{405}\right.$ values $)$ were measured with a spectrophotometer (Multiscan plus, Labsystems, Helsinki, Finland) after 1.5 to $2 \mathrm{~h}$ substrate incubation.

The inheritance of ZYFV resistance was analyzed on the basis of leaf symptoms and DAS-ELISA readings on young leaves 3 and 4 weeks after inoculation. For the genetic analysis, two independent tests were performed on parents, $\mathrm{F}_{1}, \mathrm{~F}_{2}$, and the reciprocal backcrosses.

\section{Results and Discussion}

Chlorotic lesions generally appeared on ZYFV-inoculated cotyledons or leaves of 'Marketer' and 'TMG-2' after inoculation. Severe mosaic symptoms subsequently developed on the 'Marketer' leaves, and fruit produced on these plants were small and mottled. Symptoms were absent on noninoculated 'TMG-2' leaves. The virus was detected with high $\mathrm{A}_{405}$ values in DAS-ELISA in cotyledons and leaves (inoculated or noninoculated) of 'Marketer' plants $\left(\mathrm{A}_{405}\right.$ values $\left.>1.5\right)$. Inoculated 'TMG-2' cotyledons and leaves presented variable $\mathrm{A}_{405}$ values (0.5 to 1.6$)$. The virus was detected in the first two leaves above 
the inoculated cotyledons, with a mean absorbance value $<0.6$. In the upper leaves, the virus was neither detected by DAS-ELISA nor was it recovered by back-inoculation to susceptible cucumbers.

Like plants of the susceptible parent, the $F_{1}$ plants reacted to inoculation with ZYFV with severe mosaic and high $\mathrm{A}_{405}$ values (Table 1). Mosaic symptoms similar to those in the susceptible parent developed on some $\mathrm{F}_{2}, \mathrm{BCr}$, and BC plants. No plants showed milder mosaic symptoms than those observed on the susceptible parent. The presence of symptoms was correlated with high $\mathrm{A}_{405}$ values (>1.5), and the virus was either not detected or detected only at low concentrations $\left(\mathrm{A}_{405}<0.1\right)$ in leaves without symptoms. Results of the two tests were homogeneous; $\mathrm{F}_{2}$ and $\mathrm{BCr}$ generation segregation was similar in the two tests according to a heterogeneity $\chi^{2}$ test $\left(\mathrm{F}_{2}, \chi^{2}\right.$ $=0.0004$ with $P>0.9 ; \mathrm{BCr}, \chi^{2}=0.13$ with $P>$ $0.7)$. The $\mathrm{F}_{2}$ progeny segregated for susceptibility and resistance in a 3:1 ratio. The $\mathrm{BCr}$ progeny segregated in a 1:1 ratio. All plants resulting from $\mathrm{BCs}$ were susceptible.

The frequency of ZYFV-Fr-resistant plants in progenies of a 'TMG-2' $x$ 'Marketer' cross may be explained by the action of one recessive gene (symbolized $z y f$ ). To our knowledge, this is the first report of ZYFV resistance in cucumber (Provvidenti and Hampton, 1992).

TMG previously has been resistant against several viruses (ZYMV, PRSV, WMV2, and $\mathrm{CMV}$ ), and it has excellent horticultural characteristics (Provvidenti, 1985). Studies of ge- netic relationships between these different resistances will make the selection of a multiresistant commercial cultivar easier.

\section{Literature Cited}

Avgelis, A.D. 1985. Epidemiological studies of zucchini yellow fleck virus in Crete. Phytopath. Mediterranean 24:208-210.

Baker, C.A. and D.E. Purcifull. 1987. Serological relationships of three proteins of papaya ringspot virus type W (PRSV-W) to antigens of zucchini yellowfleck virus(ZYFV).Phytopathology 77:1722.

Clark, M.F. and A.M. Adams. 1977. Characteristics of the microplate method of enzyme-linked immunosorbent assay for the detection of plant viruses. J. Gen. Virol. 34:475-483.

Cohen, S., E. Gertman, and N. Kedar. 1971. Inheritance of resistance to melon mosaic virus in cucumber. Phytopathology 61:253-255.

Gilbert-Albertini, F. and H. Lecoq. 1994. The characterization of a strain of zucchini yellow fleck virus found in southeastern France. J. Phytopath. 140:375-384

Katul,L. and K.M. Makkouk. 1987. Occurrence and serological relatedness of five cucurbit potyviruses in Lebanon and Syria. Phytopath. Mediterranean 26:36-42.

Lecoq, H., S. Cohen, M. Pitrat, and G. Labonne. 1979. Resistance to cucumber mosaic virus transmission by aphids in Cucumis melo. Phytopathology 69:1223-1225.

Lecoq, H., M. Pitrat, and M. Clement. 1981. Identification et caractérisation d'un potyvirus provoquant la maladie du rabougrissement jaune du melon. Agronomie 1:827-834.

Lisa, V. and H. Lecoq. 1984. Zucchini yellow mosaic virus. Commonwealth Mycological Insti-
tute/Association of Applied Biologists (eds.). Descriptions of plant viruses 282

Provvidenti, R. 1985. Sources of resistance in two accessions of Cucumis sativus. Cucurbit Genet. Coop. 8:12.

Provvidenti, R. 1987. Inheritance of resistance to a strain of zucchini yellow mosaic virus in cucumber. HortScience 22:102-103.

Provvidenti, R. and R.O. Hampton. 1992. Sources of resistance to viruses in the Potyviridae. Arch. Virol. Suppl. 5:189-211.

Purcifull, D., J. Edwardson, E. Hiebert, and D. Gonsalves. 1984a. Papaya ringspot virus. Commonwealth Mycological Institute/Association of Applied Biologists (eds.). Description of plant viruses 292.

Purcifull, D., E. Hiebert, and J. Edwardson. 1984b. Watermelon mosaic virus 2. Commonwealth Mycological Institute/Association of Applied Biologists (eds.). Description of plant viruses 293.

Quiot-Douine, L., H. Lecoq, J.B. Quiot, M. Pitrat, and G. Labonne. 1990. Serological and biological variability of virus isolates related to strains of papaya ringspot virus. Phytopathology 80:256-263.

Vovlas, C., A. Avgelis, and A. Quacquarelli. 1983. La "malformazione dei frutti" del cetriolo in Grecia associata al virus picchettatura gialla dello zucchino (ZYFV). Informatore Fitopatologico 33(7-8):59-60.

Vovlas, C., E. Hiebert, and M. Russo. 1981.Zucchini yellow fleck virus, A new potyvirus of zucchini squash. Phytopath. Mediterranean 20:123-128.

Wai, T. and R. Grumet. 1991. Genetic characterization of multiple potyvirus resistance in the cucumber line TMG-1. Phytopathology 81:1208.

Wang, Y.S., R. Provvidenti, and R.W. Robinson. 1984 Inheritance of resistance to watermelon mosaic virus 1 in cucumber. HortScience 19:587-588. 